\title{
PENGARUH GAYA BELAJAR TERHADAP KEMAMPUAN KOMUNIKASI MATEMATIS SISWA KELAS XI SMA ISLAM ALFALAH JAMBI
}

\author{
Vikri Hamdani $^{1}$, Buyung ${ }^{2}$, Ayu Yarmayani ${ }^{3}$ \\ Program Studi Pendidikan Matematika, FKIP, Universitas Batanghari ${ }^{1,2,3}$ \\ Jl. Slamet Riyadi No.1 Broni Jambi \\ e-mail: vikri.hamdani@gmail.com
}

\begin{abstract}
ABSTRAK
Siswa seringkali harus menempuh cara yang berbeda untuk bisa memahami sebuah informasi atau pelajaran yang sama. Cara yang cenderung dipilih siswa untuk memahami informasi inilah yang disebut sebagai gaya belajar. Gaya bersifat individual bagi setiap orang, dan untuk membedakan orang yang satu dengan orang yang lain. Jenis penelitian yang digunakan dalam penelitian ini adalah penelitian kuantitatif, yaitu penelitian yang digunakan untuk meneliti pada populasi dan sampel tertentu. Dalam penelitian ini populasi yang peneliti ambil adalah seluruh siswa kelas XI SMA Islam Al-Falah Kota Jambi. Dalam penentuan sampel, peneliti menggunakan teknik random sampling, teknik pengambilan anggota sampel dari populasi yang dilakukan secara acak tanpa memperhatikan strata yang ada dalam populasi itu. Adapun dalam penelitian ini peneliti melakukan pengambilan sampel antara 10-15\% atau 20-25\% dari populasi yang berjumlah 162 siswa. Berdasarkan deskripsi hasil penelitian dan pengolahan data melalui analisis regresi dan korelasi sederhana diperoleh informasi bahwa gaya belajar berpengaruh terhadap hasil tes kemampuan komunikasi matematis kelas XI di SMA Islam Al-Falah Jambi. Hal ini ditunjukkan oleh nilai koefisien korelasi gaya belajar visual sebesar 0,102 sehingga berada pada kategori sangat lemah, gaya belajar auditorial sebesar 0,4007 sehingga berada pada kategori cukup dan gaya belajar kinestetik sebesar 0,24 yang termasuk pada kategori lemah. Dengan demikian dapat disimpulkan bahwa ketiga gaya belajar berpengaruh terhadap kemampuan komunikasi matematis siswa kelas XI SMA Islam Al-Falah Jambi.
\end{abstract}

Kata kunci :

Gaya belajar, Kemampuan komunikasi matematis, Pengaruh

\begin{abstract}
Students often have to take different ways to understand the same information or lessons. The way students tend to understand this information is called the learning style. Style is individual for each person, and to distinguish one person from another person. This type of research used in this study is quantitative research, the research used to examine populations and certain samples. In this study the population the researchers took were all students of class XI of Al-Falah Islamic High School in Jambi City. In determining the sample, researchers used a random sampling technique, the technique of taking members of the sample from a random population without regard to strata that exist in that population. As in this study the researchers took samples between $10-15 \%$ or $20-25 \%$ of the population of 162 students. Based on the description of the results of research and data processing through regression analysis and simple correlation obtained information that learning styles affect the results of tests of mathematical communication skills of class XI at Al-Falah Islamic High School Jambi. This is indicated by the correlation coefficient value of visual learning styles of 0.102 so that it is in the very weak category, auditory learning style of 0.4007 so that it is in the sufficient category and the kinesthetic learning style of 0.24 which is included in the weak category. Thus it can be concluded that the three learning styles influence the mathematical communication skills of students of grade XI of Al-Falah Jambi Islamic High School.
\end{abstract}

Keywords :

Learning style, Mathematical communication skills, Influence

\section{PENDAHULUAN}

Pendidikan memegang peranan penting dalam mempersiapkan sumber daya manusia yang berkualitas. Matematika merupakan salah satu bidang studi yang diajarkan di dalam dunia pendidikan dari 


\section{$\pi$ (Phi)}

tingkat sekolah dasar hingga perguruan tinggi. Matematika memiliki peranan yang sangat penting dalam berbagai aspek kehidupan. Mata pelajaran matematika perlu diberikan kepada semua siswa mulai dari sekolah dasar untuk membekali siswa dengan kemampuan berpikir logis, analitis, sistematis, kritis, dan kreatif serta kemampuan bekerja sama.

Oleh karena peranan matematika yang begitu penting, sehingga mata pelajaran matematika diajarkan dari mulai tingkat sekolah dasar hingga perguruan tinggi. Permendiknas Nomor 22 Tahun 2006 menyebutkan bahwa tujuan pembelajaran matematika yaitu agar siswa memiliki kemampuan :

a. Memahami konsep matematika, menjelaskan keterkaitan antarkonsep dan mengaplikasikan konsep atau algoritma secara luwes, akurat, efisien, dan tepat dalam pemecahan masalah.

b. Menggunakan penalaran pada pola dan sifat, melakukan manipulasi matematika dalam membuat generalisasi, menyusun bukti, atau menjelaskan gagasan dan pernyataan matematika.

c. Memecahkan masalah yang meliputi kemampuan memahami masalah, merancang model matematika, menyelesaikan model, dan menafsirkan solusi yang diperoleh.

d. Mengkomunikasikan gagasan dengan simbol, tabel, diagram, atau media lain.

e. Memiliki sikap menghargai kegunaan matematika dalam kehidupan, yaitu memiliki rasa ingin tahu, perhatian, dan minat dalam mempelajari matematika, serta sikap ulet dan percaya diri dalam pemecahan masalah.

Upaya untuk mewujudkan tercapainya tujuan pembelajaran matematika bukanlah hal yang mudah. Diperlukan suatu usaha dari semua pihak, baik dari guru maupun dari siswa itu sendiri. Salah satu aspek penting yang tertera dalam tujuan pembelajaran matematika adalah kemampuan komunikasi matematis. Kemampuan komunikasi matematis merupakan suatu cara siswa untuk mengungkapkan ide-ide matematis baik secara lisan, tertulis, gambar, diagram, tabel, menyajikan dalam bentuk aljabar, atau menggunakan simbol matematika.

Berdasarkan kemampuan yang dimiliki, kemampuan seseorang untuk memahami dan menyerap pelajaran berbeda tingkatnya. Ada yang cepat, sedang, dan ada pula yang lambat. Oleh karena itu, siswa seringkali harus menempuh cara yang berbeda untuk bisa memahami sebuah informasi atau pelajaran yang sama. Cara yang cenderung dipilih siswa untuk memahami informasi inilah yang disebut sebagai gaya belajar. Gaya bersifat individual bagi setiap orang, dan untuk membedakan orang yang satu dengan orang yang lain.

Gaya belajar merupakan suatu cara mengenai bagaimana individu belajar atau cara belajar yang ditempuh oleh masingmasing orang untuk berkonsentrasi agar dapat menguasai informasi secara baik dari setiap pembelajaran yang diajarkan. Menurut Deporter (Suparman, 2010) disebutkan ada tiga macam gaya belajar yaitu gaya belajar visual, auditorial, dan kinestetik.

Menurut Ghufron dan Risnawati (2014) kemampuan seseorang untuk memahami dan menyerap pelajaran sudah pasti berbeda tingkatnya. Seorang siswa seringkali harus menempuh cara berbeda untuk bisa memahami sebuah informasi atau pelajaran yang sama. Keberagaman cara belajar yang dimiliki siswa di kelas seharusnya dapat menjadi referensi bagi seorang guru dalam mengembangkan kemampuan komunikasi matematis siswa sehingga pembelajaran yang diberikan dapat sesuai dengan kondisi siswa.

Berdasarkan hasil observasi awal yang dilakukan di SMA Islam Al-Falah Jambi, diperoleh bahwa siswa dapat menjelaskan dengan baik langkah penyelesaiaan soal hanya siswa mengalami kesulitan dalam memodelkan situasi-situasi dengan menggunakan simbol matematika. Sehingga 


\section{$\pi$ (Phi)}

berdampak kepada sulitnya siswa menyelesaikan soal-soal matematika. Mereka menganggap matematika itu sulit untuk dimengerti karena banyak menggunakan simbol, angka dan rumus yang cukup sulit untuk diingat sehingga menyebabkan rendahnya kemampuan komunikasi matematis siswa dan semua itu dipengaruhi oleh berbagai hal, misalnya gaya belajar siswa ataupun cara guru mengajar.

Berdasarkan uraian diatas, maka perlu dilakukan penelitian untuk melihat adakah pengaruh gaya belajar siswa terhadap kemampuan komunikasi matematisnya. Kemampuan komunikasi matematis pada penelitian ini dibatasi pada kemampuan komunikasi secara tertulis dengan indikator: (a) menggunakan representasi untuk menyatakan konsep matematika dan solusinya; (b) menyatakan solusi masalah menggunakan gambar, tabel, bagan, atau penyajian secara aljabar; (c) menggunakan bahasa matematika dan simbol secara tepat; (d) membuat situasi matematika dengan menyediakan ide dan keterangan dalam bentuk tertulis.

\section{METODE PENELITIAN}

Penelitian ini adalah penelitian kuantitatif, yaitu penelitian yang digunakan untuk meneliti pada populasi dan sampel tertentu. Dalam penelitian ini populasi yang peneliti ambil adalah seluruh siswa kelas XI SMA Islam Al-Falah Kota Jambi. Dalam penentuan sampel, peneliti menggunakan teknik random sampling, teknik pengambilan anggota sampel dari populasi yang dilakukan secara acak tanpa memperhatikan strata yang ada dalam populasi itu. Adapun dalam penelitian ini peneliti melakukan pengambilan sampel antara $10-15 \%$ atau $20-25 \%$ dari populasi yang berjumlah 162 siswa. Sehingga sampel penelitian sebanyak 41 orang siswa yang terdiri dari 18 orang siswa dengan gaya belajar visual, 11 orang siswa dengan gaya belajar auditorial, dan 12 orang siswa

dengan gaya belajar kinestetik. Variabel dalam penelitian ini terdiri dari (a) variabel bebas yaitu gaya belajar siswa dan (b) variabel terikat yaitu kemampuan komunikasi matematis. Berdasarkan variabelnya, teknik analisis penelitian ini menggunakan regresi linear sederhana.

Instrumen pengumpulan data dalam penelitian ini adalah berupa lembar tes kemampuan komunikasi matematis siswa dan angket. Lembar tes kemampuan komunikasi matematis yang dihasilkan dalam penelitian ini berupa lembar tes uraian yang berisi 3 soal materi program linear. Variabel gaya belajar diukur dengan menggunakan skala Likert. Hasil dari indikator variabel gaya belajar berdasarkan TCR diperoleh bahwa indikator gaya belajar visual memperoleh rata-rata 3,21 dengan Tingkat Capaian Responden (TCR) sebesar 64,19 berada pada kategori baik. Indikator gaya belajar auditorial memperoleh rata-rata 3,06 dengan Tingkat Capaian Responden (TCR) sebesar 61,26 berada pada kategori baik. Indikator dengan gaya belajar kinestetik memperoleh rata-rata 3,03 dengan Tingkat Capaian Responden (TCR) sebesar 60,65 berada pada kategori baik.

\section{HASIL DAN PEMBAHASAN}

Berdasarkan hasil penelitian statistik kemampuan komunikasi matematis siswa bergaya belajar visual, auditorial dan kinestetik. Ditinjau dari nilai rata-ratanya dari 18 orang siswa yang memiliki kemampuan komunikasi matematis bergaya visual memiliki nilai rata-rata 62,22 , nilai terendah dari 18 orang siswa ini dengan nilai 41,67 dan nilai tertinggi 95,83, median dari siswa kemampuan komunikasi matematis bergaya visual 50 dan modusnya 45,83, selanjutnya standar deviasi dan varians nya dengan nilai 15,88 dan 252,42. Ditinjau dari nilai rata-ratanya dari 11 orang siswa yang memiliki kemampuan komunikasi matematis bergaya auditorial memiliki nilai rata-rata 72,81 , nilai terendah dari 11 orang siswa ini dengan nilai 50 dan nilai tertinggi 97,91, 


\section{$\pi$ (Phi)}

median dari siswa kemampuan komunikasi matematis bergaya auditorial 70,83 dan modusnya 70,83 , selanjutnya standar deviasi dan variansnya dengan nilai 13,99 dan 195,96. Ditinjau dari nilai rata-ratanya dari 12 orang siswa yang memiliki kemampuan komunikasi matematis bergaya kinestetik memiliki nilai rata-rata 73,66 , nilai terendah dari 12 orang siswa ini dengan nilai 47,92 dan nilai tertinggi 95,83, median dari siswa kemampuan komunikasi matematis bergaya visual 72,91 dan modusnya 62,5 , selanjutnya standar deviasi dan varians nya dengan nilai 15,88 dan 252,42.

Pengujian prasyarat analisis dalam pengujian hipotesis statistik terlebih dahulu dilakukan uji prasyarat analisis. Data yang dianalisis adalah data hasil tes kemampuan komunikasi matematis siswa di kelas XI IPA 2 dan XI IPA 3. Uji prasyarat analisis pertama yang dilakukan adalah uji normalitas Liliefors. Hasil uji normalitas kelompok siswa yang memiliki gaya belajar visual memperoleh $L_{\text {hitung }}=0,1912$ yang tidak melebihi $\mathrm{L}_{\text {tabel }}=0,200$ sehingga $\mathrm{L}_{\text {hitung }}<\mathrm{L}_{\text {tabel }}$ Ini berarti kelompok siswa yang memiliki gaya belajar visual berdistribusi normal. Dari hasil uji normalitas kelompok siswa yang memiliki gaya belajar auditorial memperoleh $\mathrm{L}_{\text {hitung }}=$ 0,1881 yang tidak melebihi $\mathrm{L}_{\text {tabel }}=0,249$ sehingga $\mathrm{L}_{\text {hitung }}<\mathrm{L}_{\text {hitung. Ini berarti kelompok }}$ siswa yang memiliki gaya belajar auditorial berdistribusi normal. Sedangkan hasil uji normalitas kelompok siswa yang memiliki gaya belajar kinestetik memperoleh $\mathrm{L}_{\text {hitung }}=$ 0,1653 yang tidak melebihi $\mathrm{L}_{\text {hitung }}=0,242$ sehingga $\mathrm{L}_{\text {hitung }}<\mathrm{L}_{\text {tabel }}$. Ini berarti kelompok siswa yang memiliki gaya belajar auditorial berdistribusi normal.

Uji homogenitas dengan uji Bartlett. Hasil uji homogenitas tes kemampuan komunikasi matematis siswa diperoleh nilai varians kelompok siswa yang memiliki gaya belajar visual adalah 357,48, varians kelompok siswa yang memiliki gaya belajar auditorial adalah 195,96 dan varians kelompok siswa yang memiliki gaya belajar kinestetik adalah 252,42 sehingga didapat $\chi_{\text {hitung }}^{2}=1,17$. Pada taraf nyata $\alpha=0,05$ didapat $\quad \chi_{\text {tabel }}^{2}=5,99 \quad$ Karena nilai $\chi_{\text {hitung }}^{2}=1,17$ tidak melebihi $\chi_{\text {tabel }}^{2}=5,99$ sehingga dapat disimpulkan bahwa data hasil tes kemampuan komunikasi matematis siswa yang memiliki gaya belajar visual, auditorial dan kinestetik mempunyai varians yang homogen.

Pengujian hipotesis ini dilakukan dengan uji regresi linear sederhana. Hasil uji regresi Dari hasil analisis regresi sederhana dengan gaya belajar visual untuk uji kelinearan diperoleh $\mathrm{F}=1,459$ dan ini lebih kecil dari $\mathrm{F}_{\text {tabel }}=3,02$ sehingga hipotesis model regresi diterima (Linear). Dari hasil perhitungan koefisien korelasi dengan nilai $r$ $=0,102$, ini berarti bahwa antara gaya belajar visual dengan kemampuan komunikasi matematis terdapat hubungan positif yang sangat lemah. Dari hasil analisis regresi sederhana dengan gaya belajar auditorial untuk uji kelinearan diperoleh $\mathrm{F}=$ 0,2385 dan ini lebih kecil dari $F_{\text {tabel }}=8,84$ sehingga hipotesis model regresi diterima (Linear). Dari hasil perhitungan koefisien korelasi dengan nilai $r=0,4007$, ini berarti bahwa antara gaya belajar visual dengan kemampuan komunikasi matematis terdapat hubungan positif yang cukup berarti. Dari hasil analisis regresi sederhana dengan gaya belajar visual untuk uji kelinearan diperoleh $\mathrm{F}=0,565$ dan ini lebih kecil dari $\mathrm{F}_{\text {tabel }}=8,81$ sehingga hipotesis model regresi diterima (Linear). Dari hasil perhitungan koefisien korelasi dengan nilai $r=0,243$, ini berarti bahwa antara gaya belajar visual dengan kemampuan komunikasi matematis terdapat hubungan positif yang lemah.

Berdasarkan perhitungan dengan analisis ini, maka hasil hipotesis statistik yang didapat adalah rata-rata nilai akhir kemampuan komunikasi matematis yang dimiliki kelompok siswa bergaya belajar kinestetik lebih besar dibandingkan kelompok siswa bergaya belajar visual, kelompok siswa bergaya belajar kinestetik 


\section{$\pi$ (Phi)}

lebih besar dibandingkan kelompok siswa bergaya belajar auditorial. Maka dapat dikatakan, kelompok siswa bergaya belajar kinestetik lebih besar dibandingkan kelompok siswa bergaya belajar visual dan auditorial.

Berdasarkan hasil pengolahan data melalui analisis regresi dan korelasi sederhana diperoleh informasi bahwa gaya belajar berpengaruh terhadap hasil tes kemampuan komunikasi matematis kelas XI di SMA Islam Al-Falah Jambi. Hal ini ditunjukkan oleh nilai koefisien korelasi gaya belajar visual sebesar 0,102 sehingga berada pada kategori sangat lemah, gaya belajar auditorial sebesar 0,4007 sehingga berada pada kategori cukup dan gaya belajar kinestetik sebesar 0,24 yang termasuk pada kategori sangat lemah. Dengan demikian dapat disimpulkan bahwa ketiga gaya belajar berpengaruh terhadap kemampuan komunikasi matematis siswa kelas XI SMA Islam Al-Falah Jambi.

\section{SIMPULAN DAN SARAN}

Berdasarkan hasil pengolahan data melalui analisis regresi dan korelasi sederhana diperoleh informasi bahwa gaya belajar berpengaruh terhadap hasil tes kemampuan komunikasi matematis siswa kelas XI di SMA Islam Al-Falah Jambi. Dapat disimpulkan dengan :

1. Nilai koefisien korelasi gaya belajar visual sebesar 0,102 dengan kategori sangat lemah.

2. Nilai koefisien korelasi gaya belajar auditorial sebesar 0,4007 dengan kategori cukup.

3. Nilai koefisien korelasi gaya belajar kinestetik sebesar 0,24 dengan kategori lemah.

Dengan demikian dapat disimpulkan bahwa ketiga gaya belajar berpengaruh terhadap kemampuan komunikasi matematis siswa kelas XI SMA Islam Al-Falah Jambi.

Adapun saran yang dapat peneliti sampaikan untuk digunakan sebagai pertimbangan sesuai dengan hasil penelitian ini, yaitu:

1. Bagi siswa untuk lebih meningkatkan kemampuan komunikasi matematisnya. Untuk mengatasi kesulitan dalam menyajikan konsep melalui gambar, tabel, dan grafik. Siswa sering melakukan kesalahan dalam memberikan kesimpulan dari jawaban soal, siswa disarankan lebih teliti dalam mengerjakan soal dan lebih memperhatikan serta menyesuaikan dengan cara belajarnya.

2. Bagi setiap sekolah untuk mengadakan tes gaya belajar, agar guru tahu gaya belajar masing-masing siswa, sehingga dalam KBM guru dapat menyesuaikan gaya mengajar dengan berbagai metode yang sekiranya cocok dengan gaya belajar siswa, dengan melakukan semua ini maka akan mempertinggi efektifitas KBM di sekolah.

3. Bagi guru untuk dapat membantu berbagai masalah siswa yaitu dengan membantu siswa untuk dapat memahami kata-kata atau istilah yang muncul dalam suatu masalah sehingga kemampuan siswa khususnya kemampuan matematisnya dapat terus berkembang.

Bagi peneliti lain diharapkan dapat melakukan pembahasan yang mendalam tentang kemampuan komunikasi matematis siswa sehingga dapat mengetahui faktor selain gaya belajar yang menyebabkan kurangnya kemampuan komunikasi matematis.

\section{DAFTAR PUSTAKA}

Arikunto, Suharsimi. 2002. Prosedur Penelitian Suatu Pendekatan Praktek. Jakarta: PT. Rineka Cipta.

Ghufron, M. Nur dan Rini Risnawati. 2014. Gaya Belajar: Kajian Teoretik. Yogyakarta: Pustaka Pelajar.

Sudjana, Nana. 2005. Metoda Statistika. Bandung: Tarsito. 
Sugiyono. 2015. Metode Penelitian

Kuantitatif, $\quad$ Kualitatif,dan $\quad R \& D$.

Bandung: Alfabeta.

S, Suparman. 2010. Gaya Mengajar yang

Menyenangkan Siswa. Yogyakarta:

Pinus Book Publisher. 